\title{
Article
}

\section{Pseudomonas entomophila 23S Produces a Novel Antagonistic Compound against Clavibacter michiganensis subsp. michiganensis, a Pathogen of Tomato Bacterial Canker}

\author{
Yoko Takishita ${ }^{1}$, Alfred Souleimanov ${ }^{1}$, Carine Bourguet ${ }^{2}$, Leanne B. Ohlund ${ }^{3}$, Alexandre A. Arnold ${ }^{3}$, \\ Lekha Sleno ${ }^{3}$ (i) and Donald L. Smith ${ }^{1, *}$ \\ 1 Department of Plant Science, McGill University, Ste-Anne-de-Bellevue, QC H9X 3V9, Canada; \\ yoko.takishita@mail.mcgill.ca (Y.T.); alfred.souleimanov@mcgill.ca (A.S.) \\ 2 Drug Discovery Platform, RI-MUHC, Glen Site, Montréal, QC H3H 2R9, Canada; \\ carine.bourguet@muhc.mcgill.ca \\ 3 Department of Chemistry, Université du Québec à Montréal (UQAM), Montréal, QC H3C 3P8, Canada; \\ ohlund@gmail.com (L.B.O.); arnold.alexandre@uqam.ca (A.A.A.); sleno.lekha@uqam.ca (L.S.) \\ * Correspondence: donald.smith@mcgill.ca
}

Citation: Takishita, Y.; Souleimanov,

A.; Bourguet, C.; Ohlund, L.B.;

Arnold, A.A.; Sleno, L.; Smith, D.L.

Pseudomonas entomophila 23S Produces

a Novel Antagonistic Compound against Clavibacter michiganensis subsp. michiganensis, a Pathogen of Tomato Bacterial Canker. Appl. Microbiol. 2021, 1, 60-73. https:// doi.org/10.3390/applmicrobiol1010006

Received: 20 March 2021

Accepted: 3 May 2021

Published: 18 May 2021

Publisher's Note: MDPI stays neutral with regard to jurisdictional claims in published maps and institutional affiliations.

\section{Copyright: (c) 2021 by the authors.} Licensee MDPI, Basel, Switzerland. This article is an open access article distributed under the terms and conditions of the Creative Commons Attribution (CC BY) license (https:/ / creativecommons.org/licenses/by/ $4.0 /)$.

\begin{abstract}
Biopesticides, which consist of antagonistic microorganisms, or the bioactive compounds they produce offer attractive alternatives to synthetic agrochemicals as a means of reducing plant diseases in crop production systems. In our previous study, a strain of Pseudomonas entomophila $23 \mathrm{~S}$ was reported to have a strong antagonistic activity toward Clavibacter michiganensis subsp. michiganensis $(\mathrm{Cmm})$, a pathogen of tomato bacterial canker disease, which causes serious damage to the tomato production industry. This study focused on purification and characterization of the anti-Cmm compound(s) produced by P. entomophila 23S. The cell-free supernatant was first subjected to butanol extraction, fractioned by solid-phase extraction (SPE), and purified by highperformance liquid-chromatography (HPLC). The semi-preparative purified compounds retained anti-Cmm activity. These compounds were then characterized by liquid chromatography coupled with high-resolution tandem mass spectrometry (LC-HRMS/MS) and nuclear magnetic resonance (NMR). Two anti-Cmm compounds, $\mathrm{C}_{15} \mathrm{H}_{16} \mathrm{~N}_{2} \mathrm{O}$ and $\mathrm{C}_{16} \mathrm{H}_{18} \mathrm{~N}_{2} \mathrm{O}$, were isolated by this procedure. From the LC/MS spectra, the compounds were predicted to have an isoquinoline ring, the presence of which was confirmed by NMR. The compounds differed with respect to the presence of a methyl group in a side chain. In addition, P. entomophila $23 \mathrm{~S}$ grown in different culture media produced the greatest amounts of these anti-Cmm compounds when in Nutrient Broth (NB), where bacterial growth was the slowest. NB composition is more favorable in stimulating P. entomophila $23 \mathrm{~S}$ to produce higher amounts of these anti-Cmm compounds.
\end{abstract}

Keywords: biocontrol; tomato bacterial canker; Pseudomonas; Clavibacter michiganensis subsp. michiganensis (Cmm); biopesticides; HPLC; LC-MS/MS

\section{Introduction}

Plant diseases caused by viruses, bacteria, and fungi are responsible for significant crop losses in agriculture. Current control measures rely largely on the application of chemical pesticides [1]. However, chemical pesticides have been criticized for detrimental effects on human and environmental health [2]. Their widespread use has also resulted in development of pest resistance [3]. Because of these concerns, many pesticides are no longer available or are being targeted for removal from the marketplace [4]. Therefore, eco-friendly alternatives are urgently needed to control crop disease organisms and other pests.

Microorganism-based biological control offers an effective alternative to synthetic chemical treatment of plant diseases. Biopesticides, which consist of antagonistic microorganisms, or the bioactive compounds they produce have been increasingly researched and 
their markets are growing rapidly [5]. In general, biopesticides have the advantages of more rapid and complete biodegradation, higher selectivity, and non-target biological safety [6]. Resistance to biopesticides in target organisms is not easily developed, in contrast to the general case for their chemical counterparts [3].

Pseudomonas is a non-spore-forming, Gram-negative, rod-shaped bacterium, capable of synthesizing various antimicrobial compounds. Pseudomonas species are ubiquitously found in rhizosphere and suppressive soils and, because they are easy to isolate, culture, and manipulate genetically, these bacteria have great potential as biocontrol agents $[7,8]$. Numerous studies have been conducted on this genus and its antibiotic production potential (reviewed in [9]). Pyoluteorin; phenazine derivatives, such as phenazine-1carboxylic acid, 2,4-diacetylephloroglucinol, pyrrolnitrin, pyoluteorin, hydrogen cyanide, pyocyanin, and rhamnolipids; and protein-type compounds such as oomycin A, cepaciamide A, ecomycins, and lipopeptides are reported to be produced by various Pseudomonas species $[6,8,10]$. In fact, Pseudomonas is one of the major biocontrol agents currently used for controlling plant diseases [9].

In our previous work [11], the rhizospheric bacteria Pseudomonas entomophila $23 \mathrm{~S}$ was screened for antimicrobial activity and showed strong antagonistic activity against the plant pathogen, Clavibacter michiganensis subsp. michiganensis (Cmm). Cmm is a Gram-positive bacterium and a causal agent of bacterial canker, one of the most destructive diseases in tomato $[12,13]$. Through wounds and natural openings such as stomata and hydathodes, $\mathrm{Cmm}$ enters the plants and moves to the xylem where it multiplies rapidly [14-16]. Infected plants initially exhibit marginal necrosis of leaflets, which gradually widens and leads to wilting of all leaves as canker develops in the stem [13]. The whole plant can be stunted, severely wilted, and, ultimately, killed. Infected fruits are malformed and/or develop distinctive raised dark-spots-generally known as "bird's-eye" lesions [17]. The disease is reported in most tomato production systems in the world and causes substantial crop losses [18].

Despite its seriousness, no control methods have been found to be completely effective for tomato bacterial canker disease. No $\mathrm{Cmm}$-resistant seeds are commercially available. Current control primarily relies on the use of pathogen-free certified seeds and transplants, good hygiene, disinfection of all tools, and crop rotations [19]. Use of antibiotics or coppercontaining compounds have shown only limited efficacy $[20,21]$. Efforts are ongoing to find effective methods for management of this disease. Recently, several studies have identified bacteria, fungi, plant extracts, and insect extracts that possess anti-Cmm activity and/or showed effective disease control in tomato plants: strains of Pseudomonas sp. [22-24] and Pseudozyma aphidis yeast-type fungi [25], extracts from plants [26,27], and insects [28]. Other than from biological sources, anti-Cmm compounds have also been identified and studied by screening existing chemical libraries: synthetic peptides [29] and 12 small molecules [19].

In addition to having antagonistic activity against $\mathrm{Cmm}$ in vitro, P. entomophila $23 \mathrm{~S}$ was also observed to have biocontrol ability in vivo, by inducing systemic resistance in tomato plants infected with $\mathrm{Cmm}$ [7]. Thus, this strain has the potential as a biopesticide agent for effective control of bacterial canker. In this study, the purification and characterization of novel anti-Cmm compounds produced by P. entomophila $23 \mathrm{~S}$ is reported. The cell-free supernatant was first subjected to butanol extraction, fractioned by solid-phase extraction (SPE), purified by high-performance-liquid-chromatography (HPLC), and characterized by liquid chromatography coupled with high-resolution tandem mass spectrometry (LCHRMS/MS). In addition, some details were confirmed using nuclear magnetic resonance (NMR).

\section{Materials and Methods}

\subsection{Bacterial Growth Conditions}

Pseudomonas entomophila $23 \mathrm{~S}$ was grown in Nutrient Broth (Difco; $8 \mathrm{~g} \mathrm{~L}^{-1}$ ) medium at $28{ }^{\circ} \mathrm{C}, 100 \mathrm{rpm}$. Clavibacter michiganensis subsp. michiganensis strain $930(\mathrm{Cmm})$ was 
provided by Agriculture, Pêcheries et Alimentation, Quebec. Cmm was grown at $28^{\circ} \mathrm{C}$, $150 \mathrm{rpm}$. Both bacteria were maintained as glycerol stocks at $-80^{\circ} \mathrm{C}$.

\subsection{Butanol Extraction of Bacterial Culture}

Pseudomonas entomophila $23 \mathrm{~S}$ was prepared in $2 \mathrm{~L}$ of broth culture, in a 4-L flask at $100 \mathrm{rpm}$, for 5 days to reach stationary phase, with a total of $16 \mathrm{~L}$ of bacterial culture produced, following the methods described in [30]. In preliminary experiments with different organic solvents, butanol extracts showed the greatest amount of anti-Cmm activity, the butanol was selected for the extraction of anti-Cmm compounds from the bacterial culture. Eight hundred $\mathrm{mL}$ of 1-butanol were then added to each $2 \mathrm{~L}$ of bacterial culture, shaken occasionally and left overnight to allow for complete phase partitioning. The upper butanol layers were collected from all the flasks and combined, and the butanol was evaporated using a rotary evaporator $\left(90 \mathrm{rpm}, 50{ }^{\circ} \mathrm{C}\right.$; Yamato, NJ, USA). The dried material remaining after the evaporation was resuspended in $30 \mathrm{~mL}$ of $10 \%$ acetonitrile $\left(\mathrm{ACN} / \mathrm{H}_{2} \mathrm{O}, v / v\right)$. The extract was then centrifuged at $4{ }^{\circ} \mathrm{C}$ and $18,000 \mathrm{rpm}$ for $30 \mathrm{~min}$ to remove large particles, and the supernatant was then filtered through a $0.22 \mu \mathrm{m}$ syringe membrane (Mixed Cellulose Ester; MilliporeSigma, Darmstadt, Germany). The filtered extract was tested for anti-Cmm activity by an agar well diffusion assay, as described below.

\subsection{Agar Well Diffusion Assay}

The agar well diffusion assay followed the general method of [31]. One hundred $\mu \mathrm{L}$ of $\mathrm{Cmm}$ culture $\left(10^{8} \mathrm{cfu} \mathrm{mL}{ }^{-1}\right)$ were spread onto a Nutrient Broth Yeast Extract (NBYE; per $\mathrm{L}$ distilled $\mathrm{H}_{2} \mathrm{O}: 8.0 \mathrm{~g}$ nutrient broth, $2.0 \mathrm{~g}$ yeast extract, $2.0 \mathrm{~g} \mathrm{~K}_{2} \mathrm{HPO}_{4}, 0.5 \mathrm{~g} \mathrm{KH}_{2} \mathrm{PO}_{4}$, $5.0 \mathrm{~g}$ glucose, $0.25 \mathrm{~g} \mathrm{MgSO}_{4} \bullet \mathrm{H}_{2} \mathrm{O}$, and $15 \mathrm{~g}$ agar) agar plate. Wells with a diameter of $6 \mathrm{~mm}$ were made in the plate agar with a cork borer, and $80 \mu \mathrm{L}$ of the sample extracted from P. entomophila $23 \mathrm{~S}$ culture were loaded into each well, except the control, which was loaded with $10 \%$ acetonitrile solution. The petri plates were sealed with parafilm and incubated for at least $48 \mathrm{~h}$ at $28^{\circ} \mathrm{C}$. The zone of inhibition was measured (in millimeters) as the straight-line distance from the edge of the well to the edge of the zone of inhibition.

\subsection{Solid-Phase Extraction (SPE)}

The butanol extract obtained from the above procedures and showing anti-Cmm activity in vitro was subjected to solid-phase extraction. The butanol extract $(30 \mathrm{~mL})$ was first diluted to $100 \mathrm{~mL}$ with $10 \%$ acetonitrile and then loaded onto Extract-Clean ${ }^{\mathrm{TM}} \mathrm{C} 18$ 10,000 mg (75 mL) ${ }^{-1}$ SPE cartridges (Alltech, Nicholasville, KY, USA) with $25 \mathrm{~mL}$ per column (using a total of four columns). As an eluent, acetonitrile was applied at increasing concentrations: starting from $10 \%$ at $50 \mathrm{~mL}$, then $20,30,40,50,60$, and $70 \%$ each at $25 \mathrm{~mL}$ and, lastly, $80 \%$ at $50 \mathrm{~mL}$ per column. The eluate (fractions) was collected and tested for anti-Cmm activity by the agar well diffusion assay, as described above.

For the 50,60,70, and $80 \%$ fractions, their effects on the $\mathrm{Cmm}$ growth curve were also studied. For this experiment, the fractions were lyophilized, weighed out, and resuspended in $50 \%$ acetonitrile. Ten concentrations (1.0, 2.0, 4.0, 8.0, 16, 32, 64, 128, 256, and $512 \mu \mathrm{g}$ $\mathrm{mL}^{-1}$ ) were prepared in a 96-well plate according to the microdilution method established by [32]. The initial $\mathrm{Cmm}$ culture was adjusted to $5 \times 10^{5} \mathrm{cfu} \mathrm{mL}^{-1}$ in NB medium. The $\mathrm{Cmm}$ in the NB medium without any fractions served as a growth control while the NB media without fractions and the $\mathrm{Cmm}$ served as a sterile control. The plate was incubated at $28^{\circ} \mathrm{C}$ for 2 days using a Cytation Gen $5^{\mathrm{TM}}$ Biotek microplate reader (Biotek Instruments Inc., Winooski, VT, USA). The plate was agitated through double-orbital shaking, and the optical density at $600 \mathrm{~nm}$ was measured every $6 \mathrm{~h}$. The data were analyzed with the SAS package program version 9.4 (SAS institute Inc., Cary, NC, USA) using the proc-mixed model, with time points and concentrations as fixed effects and well plates as a random effect. Tukey's test was applied for multiple comparisons with least square means when there was a significant treatment effect at the $95 \%$ confidence level $(p<0.05)$. 


\subsection{Comparisons of SPE Fractions from Different Strains}

Active SPE fractions were analyzed by HPLC but, to determine the active peaks, the SPE fractions were also prepared from the NB media only (no bacteria grown) and from another strain of Pseudomonas sp. (accession number KJ534477, hereafter referred to as Pseudomonas sp. KJ). Pseudomonas sp. KJ is a plant growth promoting rhizobacterium of tomato plants, as studied by Ricci [33]. Butanol extracts and SPE fractions from Pseudomonas $\mathrm{sp} . \mathrm{KJ}$, grown in NB media, were prepared in the same way (i.e., same volume with same extraction methods) as P. entomophila $23 \mathrm{~S}$ extracts. The butanol and SPE fractions from both sources did not show anti-Cmm activity, as indicated by agar well diffusion assay results (not shown) and, thus, this strain was used to help identify the active peaks identified by HPLC from the SPE fractions prepared from P. entomophila 23S, which had anti-Cmm activity. Preparation of the SPE fractions was conducted as described above.

\subsection{LC-HRMS/MS Analysis}

LC-MS/MS analysis was performed on a Shimadzu Nexera UHPLC (Shimadzu, Kyoto, Japan) coupled to a high-resolution Sciex Triple TOF 5600 (quadrupole time-offlight, QqTOF) system (SCIEX, Concord, ON, Canada). Samples were injected onto a Kinetex C18 $50 \times 2.1-\mathrm{mm}$ column, with solid core 1.7- $\mu \mathrm{m}$ particles $(100 \AA)$ (Phenomenex, Torrance, CA) using a Nexera UHPLC system with water (A) and ACN (B), both containing $0.1 \%$ formic acid, at a flow rate of $300 \mu \mathrm{L} \mathrm{min}{ }^{-1}\left(40{ }^{\circ} \mathrm{C}\right)$. The gradient started at $20 \% \mathrm{~B}$, was held for $1 \mathrm{~min}$, and was then linearly increased to $50 \% \mathrm{~B}$ at $12 \mathrm{~min}$, to $85 \% \mathrm{~B}$ at $14 \mathrm{~min}$, and held for $2 \mathrm{~min}$ before column re-equilibration. MS and MS/MS spectra were collected in positive and negative ion modes using a DuoSpray ion source at $5 \mathrm{kV}$ source voltage, $450{ }^{\circ} \mathrm{C}$ source temperature, and $50 \mathrm{psi}$ GS1/GS2 gas flows, with a declustering potential of $80 \mathrm{~V}$. The instrument performed a survey TOF-MS acquisition from $\mathrm{m} / \mathrm{z} 80$ to 1000 (150-ms accumulation time), followed by MS/MS on precursor ions $\mathrm{m} / z 241.135$ and 255.1505. Each MS/MS acquisition had an accumulation time of $150 \mathrm{~ms}$ and with collision energy of 30 V. High-resolution MS/MS spectra were visualized using PeakView software (Sciex, version 2.1).

\subsection{HPLC Semi-Preparative Purification}

Purification of extracts was conducted on a semi-preparative scale $\left(5 \mathrm{~mL} \min ^{-1}\right)$, Agilent 1260 Infinity HPLC system (Agilent Technologies, Santa Clara, CA, USA), with UV detection at $254 \mathrm{~nm}$ (see results for more information of fractions purified). Samples were concentrated by drying under nitrogen until approximately one-half of the original volume remained. Concentrated samples were centrifuged ( $5 \mathrm{~min} ; 140,000 \mathrm{rpm}$ ) and the supernatant was transferred to vials. An Agilent Pursuit XRs C18 column (5 $\mu \mathrm{m} ; 250 \times$ $10 \mathrm{~mm}$ ) was employed at a flow rate of $5 \mathrm{~mL} \mathrm{~min}^{-1}$. Mobile phases $A$ and $B$ were water and acetonitrile, both containing $0.1 \%$ formic acid. The gradient started at $30 \% \mathrm{~B}$, which was held for $1 \mathrm{~min}$ after sample injection. The mobile phase B was then increased to $70 \%$ from 1-4 min and then to $85 \%$ for $4-14 \mathrm{~min}$. Next, the column was washed at $95 \%$ B from $14.5-16 \mathrm{~min}$, prior to re-equilibration at $30 \%$ B. Sample injection volume was $900 \mu \mathrm{L}$. Fractions collected were analyzed by LC-UV-MS and then subjected to biological testing to confirm activity.

\subsection{LC-UV-MS Analysis of HPLC Purified Fractions}

LC-UV-MS analysis was performed on an Agilent 1200 HPLC coupled to an Agilent 6210 ESI-TOF mass spectrometer. HPLC fractions were injected onto an Eclipse Plus C18 column ( $50 \times 3 \mathrm{~mm}, 1.8$ - $\mu \mathrm{m}$ particles) (Agilent Technologies, Santa Clara, CA, USA) with water (A) and $\mathrm{ACN}(\mathrm{B})$, both containing $0.1 \%$ formic acid, at a flow rate of $400 \mu \mathrm{L} \mathrm{min}{ }^{-1}$. The gradient started at $30 \% \mathrm{~B}$, was held for $1 \mathrm{~min}$, and was then linearly increased to $50 \%$ B over $4 \mathrm{~min}$, to $75 \% \mathrm{~B}$ at $11 \mathrm{~min}$, to $95 \%$ at $11.5 \mathrm{~min}$, and held for $2.5 \mathrm{~min}$ before column reequilibration. The UV detector was set to $254 \mathrm{~nm}$ and MS spectra were collected in positive 
ion mode from $m / z$ 100-1000. High-resolution MS spectra were internally calibrated for accurate mass measurements.

\subsection{NMR Characterization of HPLC Fraction 1}

NMR spectra were acquired on a Bruker Avance III-HD using a double-resonance, 5 -mm BBFO probe. Samples were dissolved in methanol- $\mathrm{d}_{4}$ and ${ }^{1} \mathrm{H}, \mathrm{COSY},{ }^{13} \mathrm{C}$, and ${ }^{1} \mathrm{H}-{ }^{13} \mathrm{C}$ HSQC spectra with multiplicity edition spectra recorded at room temperature. The ${ }^{1} \mathrm{H}$ and ${ }^{13} \mathrm{C} 90^{\circ}$ pulses were 12.9 and $12 \mu \mathrm{s}$, respectively. Recycle delays were $1 \mathrm{~s}$ for the $1 \mathrm{H}$ spectrum and $1.4 \mathrm{~s}$ for all other spectra. Acquisition times were $2.7 \mathrm{~s}\left({ }^{1} \mathrm{H}\right), 0.128 \mathrm{~s}(\mathrm{COSY})$, $0.9 \mathrm{~s}\left({ }^{13} \mathrm{C}\right)$, and $0.166 \mathrm{~s}$ (HSQC). Sixty-four transients were accumulated for the ${ }^{1} \mathrm{H}$ spectrum and 1024 for the ${ }^{13} \mathrm{C}$ spectrum. For the COSY spectrum, two scans were accumulated for each of the 256 increments in the indirect dimension and the spectral widths were $13.36 \mathrm{ppm}$. For the HSQC spectrum, two scans were accumulated for each of the 648 increments in the indirect dimension and the spectral widths were $10.29 \mathrm{ppm}\left({ }^{1} \mathrm{H}\right)$ and $180 \mathrm{ppm}\left({ }^{13} \mathrm{C}\right)$. All spectra were referenced with respect to the residual methanol peak calibrated at $3.31 \mathrm{ppm}$.

\subsection{Effects of Media on Anti-Cmm Activity of Butanol Extracts}

In addition, butanol extracts were also prepared from three additional media (other than NB): (1) King's B (KB), (2) Luria Broth (LB), and (3) Tryptic Soy Broth (TSB). Preparation of KB, LB, and TSB were prepared as follows: for $\mathrm{KB}$, per $\mathrm{L}$ of distilled $\mathrm{H}_{2} \mathrm{O}$ - proteose peptone No.3 $20 \mathrm{~g}$, glycerol $10 \mathrm{~mL}, \mathrm{~K} 2 \mathrm{HPO} 41.5 \mathrm{~g}$, MgSO4 $1.5 \mathrm{~g}$; for LB, per L of distilled $\mathrm{H}_{2} \mathrm{O}$ - tryptone $10 \mathrm{~g}$, NaCl $10 \mathrm{~g}$, yeast extract $5 \mathrm{~g}$; and for TSB, per $\mathrm{L}$ of distilled $\mathrm{H}_{2} \mathrm{O}$ tryptic soy broth $30 \mathrm{~g}$. Pseudomonas entomophila $23 \mathrm{~S}$ was grown in each medium and extracted with butanol as described above and the four extracts were tested for anti- $\mathrm{Cmm}$ activity. At the same time, the effect of each medium on the growth rate of P. entomophila $23 S$ was studied by using a 96-well plate, which was read for cell density at regular intervals. The initial culture was adjusted to $5 \times 10^{5} \mathrm{cfu} \mathrm{mL}^{-1}$ for each medium and $100 \mu \mathrm{L}$ was applied in each well. Each medium, without the culture, served as a sterile control. The plate was incubated at $28^{\circ} \mathrm{C}$ for 2 days using the Cytation Gen $5^{\mathrm{TM}}$ Biotek microplate reader. The plate was double orbitally shaken, and the optical density at $600 \mathrm{~nm}$ was measured every $2 \mathrm{~h}$. The data were analyzed with the SAS package program version 9.4 (SAS institute Inc., Cary, NC, USA) using the proc-mixed model, with time points and concentrations as fixed effects. Tukey's test was applied for multiple comparisons for the least square means when there was a significant treatment effect at the $95 \%$ confidence level $(p<0.05)$.

\subsection{Effects of the Two Purified Anti-CMM Compounds on Cmm Growth Curves}

The two isolated anti-Cmm compounds were used to monitor their effects on $\mathrm{Cmm}$ growth. The experiment was performed in the same manner as the study of the effects of SPE fraction on the Cmm growth curve, as described above, by using a Gen $5^{\mathrm{TM}}$ Biotek microplate reader. Due to the limited amounts of purified compounds obtained, the tested concentration was $0.5-32 \mu \mathrm{g} \mathrm{mL} \mathrm{m}^{-1}$ for the first compound $\left(\mathrm{m} / \mathrm{z} 241\left(\mathrm{MH}^{+}\right)\right)$and was $0.5-256 \mu \mathrm{g} \mathrm{mL} \mathrm{m}^{-1}$ for the second compound $\left(\mathrm{m} / \mathrm{z} 255\left(\mathrm{MH}^{+}\right)\right)$.

\section{Results}

\subsection{Anti-Cmm Activity of Butanol Extract and Anti-Cmm Activity of Solid-Phase Extraction (SPE) Fractions}

The butanol extract, obtained from P. entomophila 23S grown in NB media, was tested for anti-Cmm activity with a disk diffusion assay on NBY plates (Figure 1), resulting in the inhibition of $\mathrm{Cmm}$ growth, as indicated by zone of inhibition $(10 \mathrm{~mm})$. 


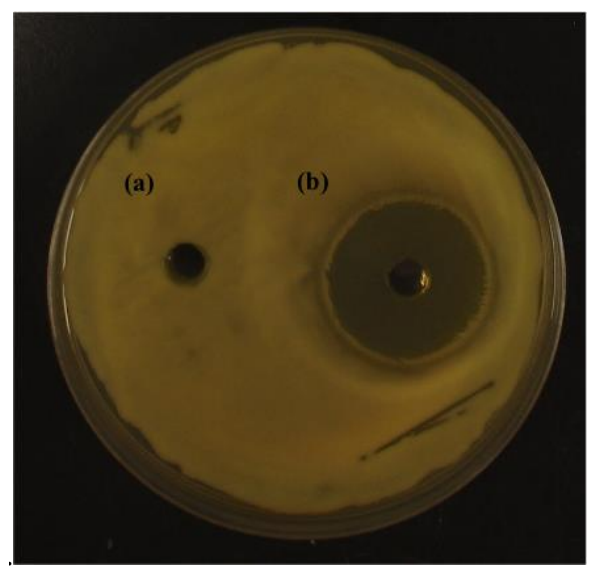

Figure 1. Anti-Cmm activity of butanol extract of P. entomophila 23S: $10 \%$ acetonitrile (control; (a)) and butanol extract $(\mathbf{b})$.

The butanol extract was then subjected to solid-phase extraction (SPE), using 10 to $80 \%$ $\mathrm{ACN}$ as eluent, and each fraction was assessed for anti-Cmm activity. The disk diffusion assay showed that among the eight fractions, the 50,60,70, and 80\% SPE fractions inhibited the growth of $\mathrm{Cmm}$, as indicated by zone of inhibition (Table 1 ).

Table 1. Anti-Cmm activity of SPE fractions.

\begin{tabular}{cc}
\hline $\begin{array}{c}\text { \% Acetonitrile } \\
\text { (in Fractions) }\end{array}$ & $\begin{array}{c}\text { Zone of Inhibition } \\
(\mathbf{m m})\end{array}$ \\
\hline $10-40 \%$ & $\mathrm{n} / \mathrm{a}$ \\
50 & 4 \\
60 & 20 \\
70 & 14 \\
80 & 11 \\
\hline
\end{tabular}

In addition, the 50, 60, 70, and $80 \%$ SPE fractions were also used to study their effect, at different concentrations, on $\mathrm{Cmm}$-growth curves using spectrophotometry (Figure 2). When statistical tests were performed, the concentrations that significantly inhibited the growth of $C \mathrm{~mm}$, as compared with control, were: $64,128,256$, and $512 \mu \mathrm{g} \mathrm{mL}^{-1}$ for the $50 \%$ fraction; 128,256 , and $512 \mu \mathrm{g} \mathrm{mL}-1$ for the $60 \%$ fraction; 128,256 , and $512 \mu \mathrm{g} \mathrm{mL} \mathrm{m}^{-1}$ for the $70 \%$ fraction; and $64,128,256$, and $512 \mu \mathrm{g} \mathrm{mL} \mathrm{m}^{-1}$ for the $80 \%$ fraction. The effects of other concentrations were not significantly different from those of the control and some actually enhanced the growth of $\mathrm{Cmm}$. 

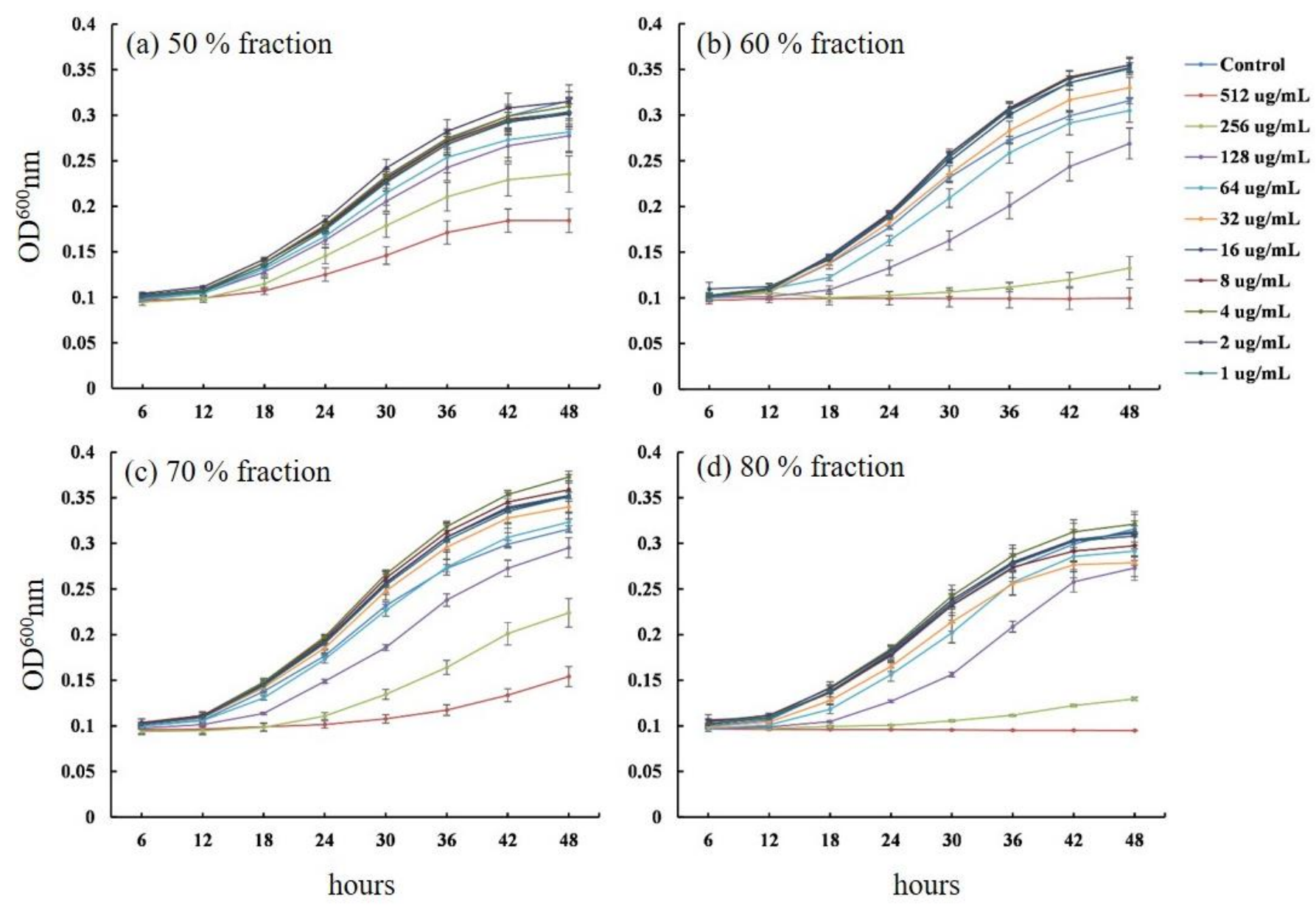

Figure 2. Effects of SPE fractions on Cmm growth. Fractions collected by SPE were freeze-dried and resuspended in acetonitrile, from: (a) 50\% fraction, (b) 60\% fraction, (c) 70\% fraction, and (d) $80 \%$ fraction.

\subsection{LC-MS Analysis of SPE Fractions from Two Strains of Pseudomonas}

To characterize the SPE anti-Cmm peaks produced by P. entomophila 23S, SPE fractions were prepared from three sources: (1) NB media only, (2) P. entomophila 23S grown in NB, and (3) Pseudomonas sp. strain KJ grown in NB. Because the fractions prepared from the NB media only, or from the Pseudomonas sp. strain KJ grown in NB, did not possess anti-Cmm activities, the unique peaks seen in the LC-MS analysis of the three fractions $(60,70$, and $80 \% \mathrm{ACN}$ ) from the $23 \mathrm{~S}$ strain were tentatively deemed responsible for the anti-Cmm biological activity. Two peaks of interest were found only in the $23 \mathrm{~S}$ strain fractions and are shown in Figure 3a, where extracted ion chromatograms were overlaid for the three samples (NB media control and the two strains grown in NB). These two peaks of interest yielded protonated molecules with mass-to-charge ratios $(\mathrm{m} / \mathrm{z})$ of 241.1341 and 255.1499, corresponding to neutral formulae of $\mathrm{C}_{15} \mathrm{H}_{16} \mathrm{~N}_{2} \mathrm{O}$ (2.4 ppm mass error) and $\mathrm{C}_{16} \mathrm{H}_{18} \mathrm{~N}_{2} \mathrm{O}$ $(2.9 \mathrm{ppm})$, respectively. Figure $3 \mathrm{~b}$ shows the high-resolution MS/MS spectra for these two protonated molecules. 


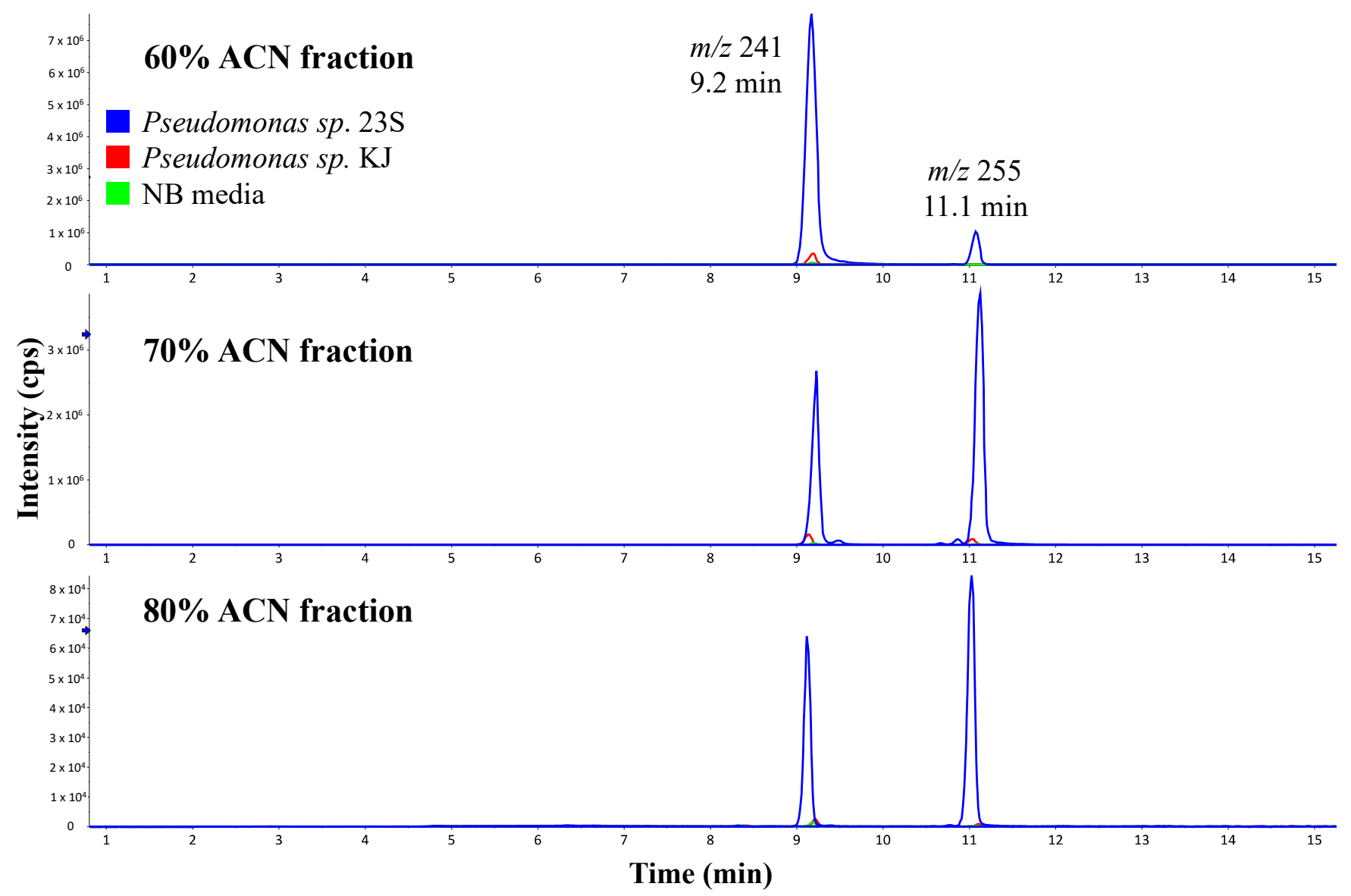

(a)

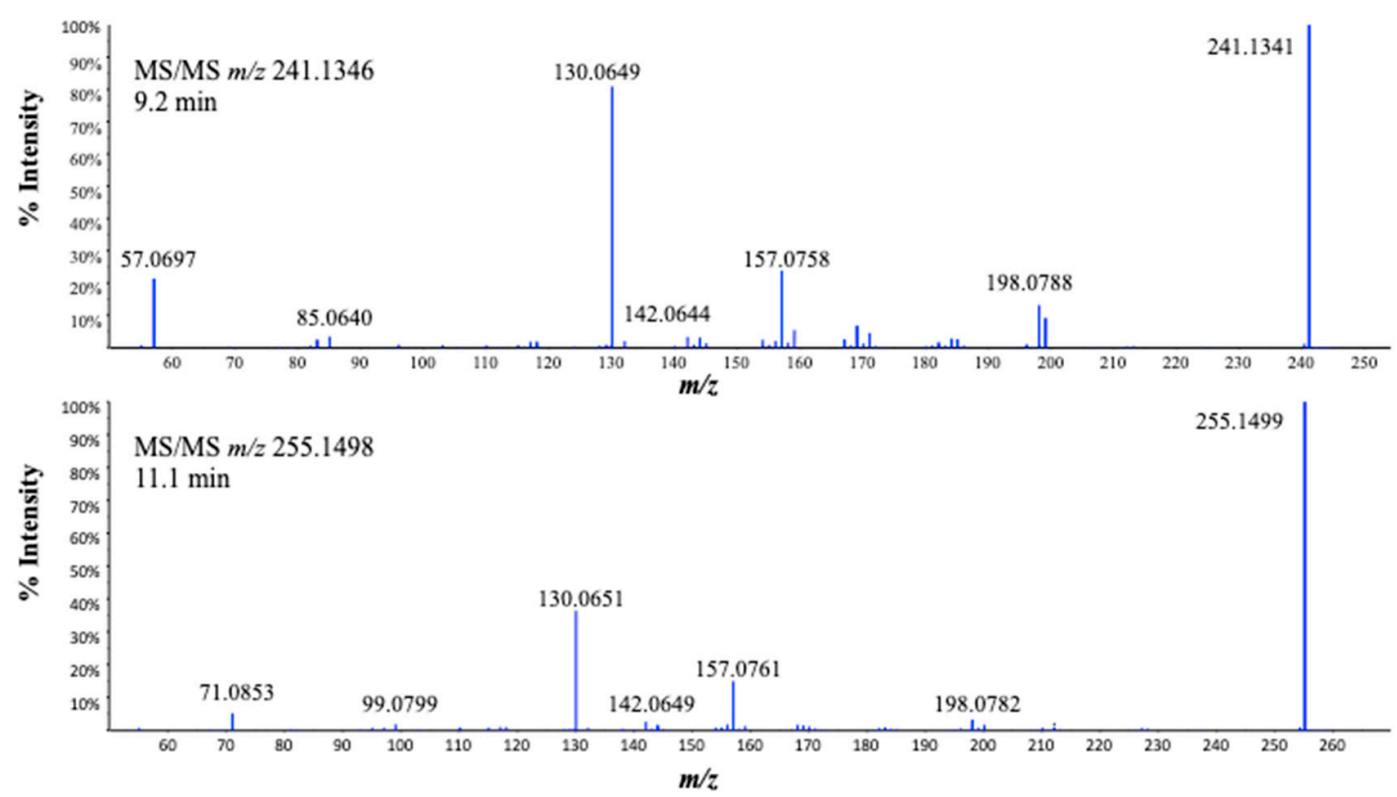

(b)

Figure 3. Extracted ion chromatograms from SPE fractions of two peaks of interest, selectively found in $23 \mathrm{~S}$ strain, found at $m / z 241$, and 255 as protonated molecules $\left(\mathrm{MH}^{+}\right)(\mathbf{a})$ and high-resolution MS/MS spectra for compounds found at $m / z 241$ and 255 (b). 
From this data, the formulae for fragment ions were confirmed (Tables 2 and 3) and, hence, elucidating certain structural features of these compounds was possible. It was apparent that the two compounds were structurally very similar, with only one $\mathrm{CH}_{2}$ group difference. By studying the fragmentation pathways, these compounds were tentatively determined to contain an isoquinoline ring system as well as an alkyl side chain, where the mentioned extra $\mathrm{CH}_{2}$ group was present in the protonated molecule at $m / z 255$. Two of the most active SPE fractions (60 and 70\%) were subjected to HPLC purification to better characterize the putative biologically active compounds. From the $60 \% \mathrm{SPE}$ fraction, three fractions were collected. From the 70\% SPE fraction, two fractions were collected. Representative HPLC traces from this purification showing the fractionation windows collected are provided as Supplementary Figure S1. The fractions were tested for purity by LC-UV-TOF-MS (see Methods) and five out of six were found to contain only one peak of interest in the UV and total ion chromatogram traces. Fraction 3 from the $60 \%$ sample and Fraction 1 from the $70 \%$ samples had a protonated molecule at $m / z 241.1348$ and Fraction 2 from the 70\% sample showed a protonated molecule at $m / z 255.1490$ (Supplementary Figure S2).

Table 2. Predominant product ions seen in MS/MS spectrum of $m / z 241$ compound, showing elemental formulae for each, confirmed by accurate mass data, and corresponding neutral losses ( ${ }^{*}$ denotes radical species).

\begin{tabular}{ccccc}
\hline$m / z$ & $\begin{array}{c}m / z \\
\text { Calculated }\end{array}$ & $\begin{array}{c}\text { Ion } \\
\text { Formula }\end{array}$ & ppm & Neutral Loss \\
\hline 57.0697 & 57.0699 & $\mathrm{C}_{4} \mathrm{H}_{9}{ }^{+}$ & -3.9 & $\mathrm{C}_{11} \mathrm{H}_{8} \mathrm{~N}_{2} \mathrm{O}$ \\
85.0640 & 85.0648 & $\mathrm{C}_{5} \mathrm{H}_{9} \mathrm{O}^{+}$ & -9.0 & $\mathrm{C}_{10} \mathrm{H}_{8} \mathrm{~N}_{2}$ \\
130.0649 & 130.0651 & $\mathrm{C}_{9} \mathrm{H}_{8} \mathrm{~N}^{+}$ & -1.9 & $\mathrm{C}_{6} \mathrm{H}_{9} \mathrm{NO}$ \\
142.0644 & 142.0651 & $\mathrm{C}_{10} \mathrm{H}_{8} \mathrm{~N}^{+}$ & -5.0 & $\mathrm{C}_{5} \mathrm{H}_{9} \mathrm{NO}$ \\
157.0758 & 157.0760 & $\mathrm{C}_{10} \mathrm{H}_{9} \mathrm{~N}_{2}{ }^{+}$ & -1.4 & $\mathrm{C}_{5} \mathrm{H}_{8} \mathrm{O}$ \\
198.0788 & 198.0788 & $\mathrm{C}_{12} \mathrm{H}_{10} \mathrm{~N}_{2} \mathrm{O}^{+*}$ & -0.3 & $\mathrm{C}_{3} \mathrm{H}_{7}$ \\
241.1341 & 241.1335 & $\mathrm{C}_{15} \mathrm{H}_{17} \mathrm{~N}_{2} \mathrm{O}^{+}$ & 2.4 & \\
\hline
\end{tabular}

Table 3. Predominant product ions seen in MS/MS spectrum of $\mathrm{m} / \mathrm{z} 255$ compound, showing elemental formulae for each, confirmed by accurate mass data, and corresponding neutral losses ( ${ }^{*}$ denotes radical species).

\begin{tabular}{ccccc}
\hline$m / z$ & $\begin{array}{c}m / z \\
\text { Calculated }\end{array}$ & $\begin{array}{c}\text { Ion } \\
\text { Formula }\end{array}$ & ppm & Neutral Loss \\
\hline 71.0853 & 71.0855 & $\mathrm{C}_{5} \mathrm{H}_{11}{ }^{+}$ & -3.0 & $\mathrm{C}_{11} \mathrm{H}_{8} \mathrm{~N}_{2} \mathrm{O}$ \\
99.0799 & 99.0804 & $\mathrm{C}_{6} \mathrm{H}_{11} \mathrm{O}^{+}$ & -5.3 & $\mathrm{C}_{10} \mathrm{H}_{8} \mathrm{~N}_{2}$ \\
130.0651 & 130.0651 & $\mathrm{C}_{9} \mathrm{H}_{8} \mathrm{~N}^{+}$ & -0.3 & $\mathrm{C}_{7} \mathrm{H}_{11} \mathrm{NO}$ \\
142.0649 & 142.0651 & $\mathrm{C}_{10} \mathrm{H}_{8} \mathrm{~N}^{+}$ & -1.3 & $\mathrm{C}_{6} \mathrm{H}_{11} \mathrm{NO}$ \\
157.0761 & 157.0760 & $\mathrm{C}_{10} \mathrm{H}_{9} \mathrm{~N}_{2}{ }^{+}$ & 0.3 & $\mathrm{C}_{6} \mathrm{H}_{10} \mathrm{O}$ \\
198.0782 & 198.0788 & $\mathrm{C}_{12} \mathrm{H}_{10} \mathrm{~N}_{2} \mathrm{O}^{+*}$ & -2.8 & $\mathrm{C}_{4} \mathrm{H}_{9}{ }^{*}$ \\
255.1499 & 255.1492 & $\mathrm{C}_{16} \mathrm{H}_{19} \mathrm{~N}_{2} \mathrm{O}^{+}$ & 2.9 & \\
\hline
\end{tabular}

After multiple HPLC injections, appropriate fractions were pooled, concentrated under nitrogen, and then subjected to LC-MS/MS and NMR analysis, as well as testing for biological activity (Supplementary Figure S3). Peaks eluting at 9.7 and $11.3 \mathrm{~min}$ were collected and pooled into Fractions 1 and 2, respectively. LC-MS/MS analysis confirmed these two fractions to be the two compounds of interest at $m / z 241$ and 255, respectively. NMR analysis was conducted on the first collected fraction, as the concentration and purity of the second fraction were not high enough for proper structural characterization. The ${ }^{1} \mathrm{H}$ and COSY NMR spectra were acquired (Supplementary Figure S4.1), and HSQC analysis (Supplementary Figure S4.2) confirmed the presence of the quinolone ring as well as the terminal alkyl chain, as proposed in Figure S3. While an absolute structure of this compound could not be confirmed at this time, there was compelling evidence for it. The NMR 
spectra for the first compound $(\mathrm{m} / \mathrm{z} 241)$ were consistent with the high-resolution MS/MS data. The proposed fragmentation of both protonated and deprotonated precursors are shown in supplemental figures (Supplementary Figures S5 and S6). The second compound $(\mathrm{m} / \mathrm{z} 255)$ differed from the first compound $(\mathrm{m} / \mathrm{z} 241)$ by $\mathrm{CH}_{2}$, as suggested by the MS/MS data, in the terminal alkyl chain of the molecule.

\subsection{Effects of Different Media on Anti-Cmm Activity of Butanol Extracts}

Butanol extracts were prepared with $P$. entomophila $23 S$ grown in different culture media, King's B (KB), Luria broth (LB), and tryptic soy broth (TSB), to compare the relative amounts of putative anti-Cmm compounds produced when the bacterium was grown in NB. Only the butanol extracts made from NB-grown culture showed anti-Cmm activity (Supplementary Figure S7).

To investigate whether differences in the anti-Cmm activity of butanol extracts prepared from different media were due to the number of cells, growth of the P. entomophila $23 \mathrm{~S}$ was compared when it was grown in NB, KB, LB, and TSB (Supplementary Figure S7e). Statistical analysis indicated that the growth of the P. entomophila $23 \mathrm{~S}$ began to differ at $8 \mathrm{~h}$. The value of optical density $\left(\mathrm{OD}_{600}\right)$ was significantly higher for the TSB than other media. At the same time, the value for NB was significantly lower than for other media. This trend continued to develop during the $20 \mathrm{~h}$ of growth.

In addition, the four butanol extracts were analyzed by LC-MS and checked for the presence of the two active compounds $\left(\mathrm{C}_{15} \mathrm{H}_{16} \mathrm{~N}_{2} \mathrm{O}\right.$ and $\left.\mathrm{C}_{16} \mathrm{H}_{18} \mathrm{~N}_{2} \mathrm{O}\right)$. As shown by the overlaid, extracted ion chromatograms from LC-MS analysis (Figure 4), peaks for protonated ions at $m / z 241$ and 255 were both present for all four media. However, the peak intensities for the NB-prepared butanol extracts were much higher than those for KB-, LB-, and TSB-prepared butanol extracts.

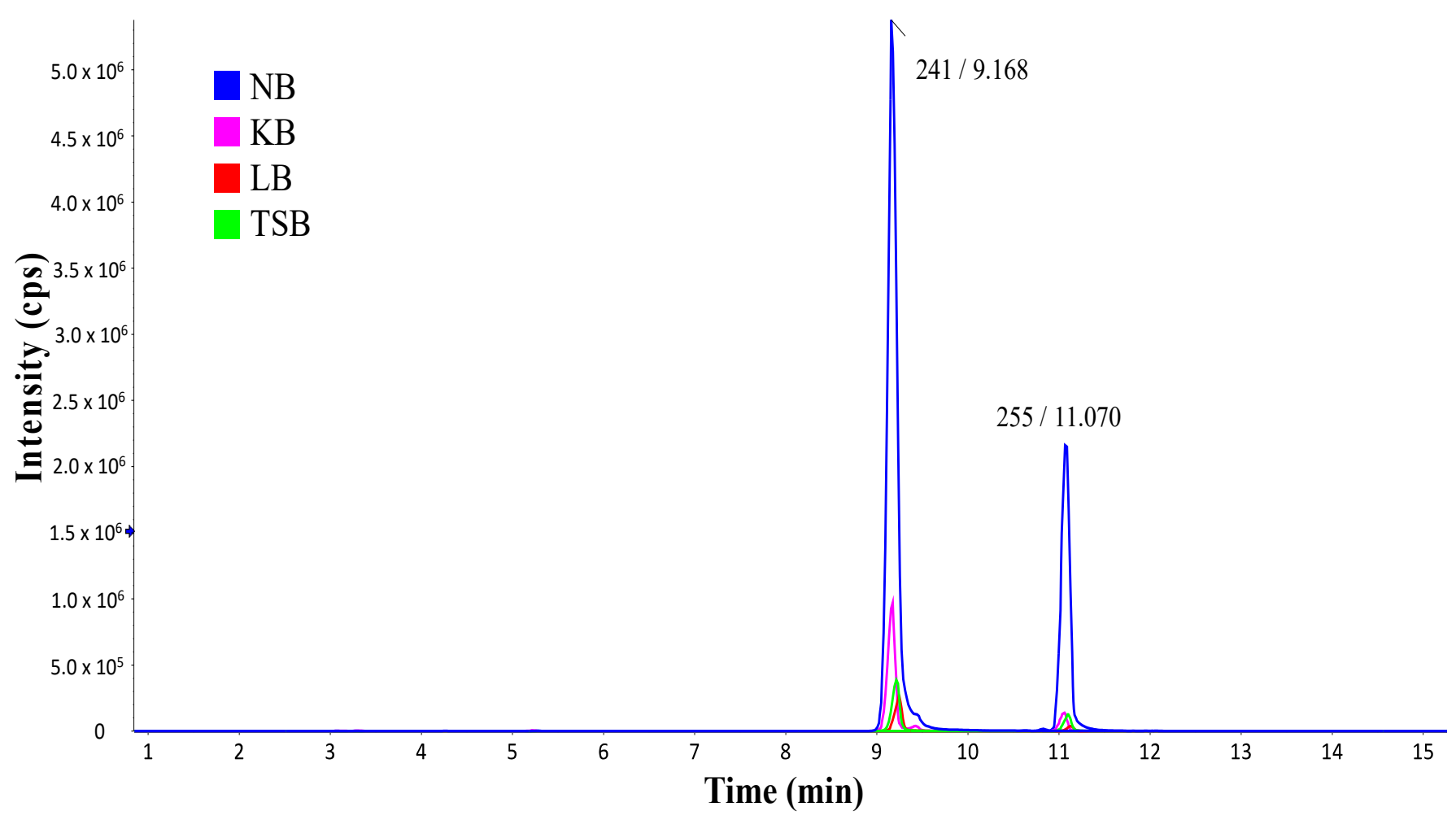

Figure 4. Representative high-resolution extracted ion chromatograms (left) and mass spectra (right) for two fractions (F1 and F2) from 70\% SPE sample, purified by HPLC. F1 and F2 contain molecular species, giving $\mathrm{MH}^{+}$at $\mathrm{m} / \mathrm{z} 241.1348$ and $\mathrm{m} / \mathrm{z}$ 255.1490, respectively. The complete ion chromatograms and UV traces (at $254 \mathrm{~nm}$ ) showed no other peaks present in these purified fractions. 


\subsection{Effects of Two Purified Anti-Cmm Compounds on Cmm Growth Curve}

The two isolated anti-Cmm compounds were also studied in terms of their effects on the $\mathrm{Cmm}$ growth curve by spectrophotometry (Figure 5). For the first compound $\left(\mathrm{C}_{15} \mathrm{H}_{16} \mathrm{~N}_{2} \mathrm{O}, \mathrm{m} / z 241\right)$, all the concentrations used, from 0.5 to $32 \mu \mathrm{g} \mathrm{mL} \mathrm{m}^{-1}$, significantly inhibited the growth of $\mathrm{Cmm}$ when compared with control. For the second compound $\left(\mathrm{C}_{16} \mathrm{H}_{18} \mathrm{~N}_{2} \mathrm{O}, \mathrm{m} / \mathrm{z} 255\right)$, concentrations ranging from 16 to $254 \mu \mathrm{g} \mathrm{mL}{ }^{-1}$ significantly suppressed the $\mathrm{Cmm}$ growth, as compared with the control, while concentrations between 1.0 to $8.0 \mu \mathrm{g} \mathrm{mL}^{-1}$ promoted $\mathrm{Cmm}$ growth.

(a)

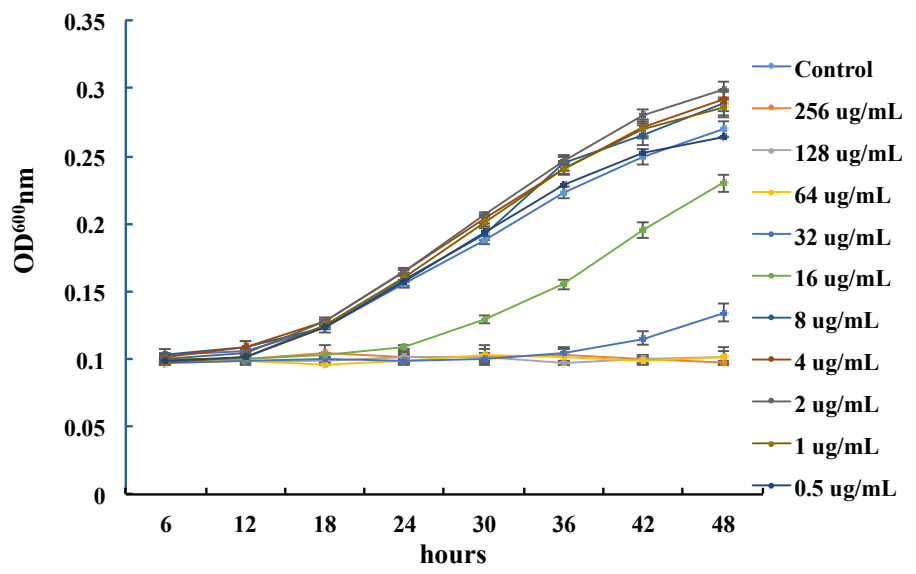

(b)

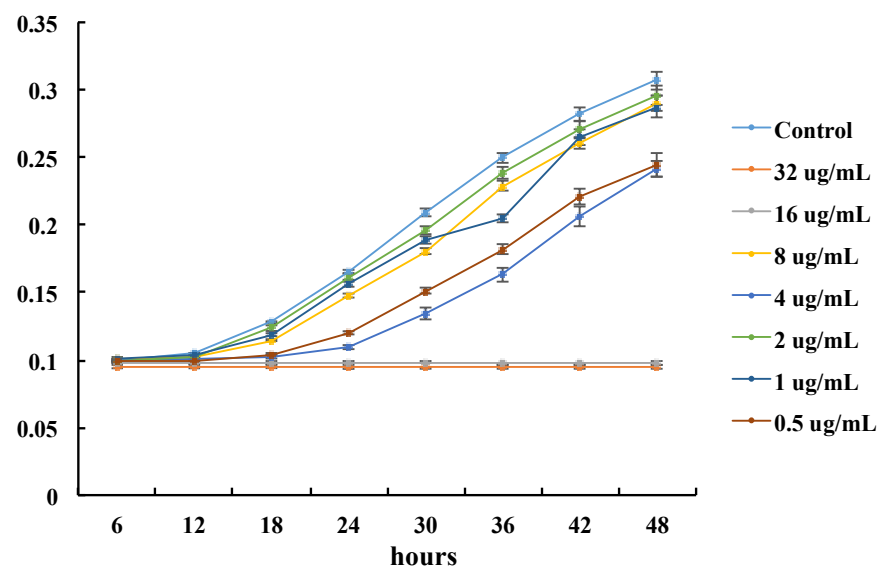

Figure 5. Effects of the two purified anti-Cmm compounds, $m / z=214$ (a) and $m / z=255$ (b), on Cmm growth.

\section{Discussion}

Butanol extracts, prepared from cultures of the P. entomophila $23 \mathrm{~S}$ clearly showed anti- $\mathrm{Cmm}$ activity, implying that the solvent extraction was efficient. Following the butanol extraction, solid-phase extraction was conducted and the results indicated that the 50,60, 70 , and $80 \%$ fractions possessed anti-Cmm activity, suggesting that the more hydrophobic fractions had inhibitory effects toward $\mathrm{Cmm}$. The size of the zone of inhibition was larger for the 60,70 , and $80 \%$ fractions than the $50 \%$ fraction, implying that the superior anti$\mathrm{Cmm}$ activities for the 60,70 , and $80 \%$ fractions were due to greater concentrations of the active material(s). In addition to the anti-Cmm compounds, some growth-promoting compounds might have been present in the fractions and, at certain concentrations, these growth-promoting effects of the fractions were greater than the growth-inhibiting effects, resulting in enhanced $\mathrm{Cmm}$ growth. This concentration-dependent effect on $\mathrm{Cmm}$ growth was also observed when $\mathrm{Cmm}$ was grown with purified compounds.

As a result of purification and analyses, we isolated two anti-Cmm compounds whose structures were identified as having isoquinoline as their largest part. Isoquinoline alkaloids containing a heterocyclic isoquinoline backbone represent a diverse group of compounds, such as antibacterial berberine and sanguinarine, antitussive and anti-cancer noscapine, anti-gout colchicine, and analgesic compounds. These compounds are valued as natural medicinal and pharmaceutical natural products $[34,35]$. They can be found commonly in plants, although a few fungal (e.g., Aspergillus fumigatus [36], Penicillium sp. [37]) and bacterial species (Streptomyces sp. [38]) produce isoquinoline alkaloids with new antibacterial activities at this time. Isoquinoline alkaloids are well known for their antimicrobial activities against a wide range of human pathogenic bacteria and phytopathogenic fungi [34,39]. For instance, recently discovered, novel isoquinoline alkaloids were confirmed for bioactivities against human pathogens, such as Bacillus cereus, Staphylococcus aureus, Salmonella typhi, and Escherichia coli 100 [40,41], as well as phytopathogenic fungi such as Fusarium culmorum and Geotrichum candidum [42]. Two modes of action have been proposed, inhibiting cell division and inhibiting nucleic acid synthesis [43], although exact actions 
were not completely elucidated [39]. Derived from tyrosine, quinoline synthesis in plants has been characterized in detail [35,44]. Xu et al. [16] reported 12 anti-Cmm compounds identified by screening a chemical library of yeast-active molecules. These compounds had piperidines, benzimidazoles, phenols, phenoxy isopropanolamines, or pyrrolidone as base structures. Isoquinoline seems not to have been previously studied or/and reported to have antimicrobial activity toward $\mathrm{Cmm}$. When PubChem (https://pubchem.ncbi.nlm.nih.gov accessed on 1 March 2021) was used to search for this isoquinoline-based structure, the system indicated that there were "zero results found", suggesting novelty for the isolated compound.

Since the largest production of anti-Cmm compounds occurred in the NB media where bacterial growth was the slowest, greater anti-Cmm activities observed from the NB extracts were not due to greater bacterial growth, but due to higher concentrations of the active compounds. The production of anti-Cmm compounds by P. entomophila $23 \mathrm{~S}$ might be occurring in response to less favorable culture nutrient conditions leading to stress. Microorganisms often switch on specific aspects of secondary metabolism under stressful conditions, as a strategy to remain competitive and survive in their environment $[9,45]$. Among the four media tested, P. entomophila $23 S$ grew best in TSB. The main difference between TSB and other media is that TSB contains soybean meal, a plant component. Pseudomonas entomophila $23 \mathrm{~S}$ was originally isolated from the rhizosphere of soybean plants [7]. Thus, the TSB might have been more favorable for growth of this bacterium than the other evaluated media. Specific ingredients, or the lack thereof, in the NB media may be acting to inhibit the growth of P. entomophila $23 S$ and, at the same time, resulting in induced stress, causing the bacteria to produce anti-Cmm compounds in this medium at much higher levels.

In this study, the two isolated compounds from P. entomophila $23 \mathrm{~S}$ inhibited Cmm growth. Although their full structures were not confirmed, the data indicated that these compounds, with molecular formulae of $\mathrm{C}_{15} \mathrm{H}_{16} \mathrm{~N}_{2} \mathrm{O}$ and $\mathrm{C}_{16} \mathrm{H}_{18} \mathrm{~N}_{2} \mathrm{O}$, differ only by one $\mathrm{CH}_{2}$ group and that both have an isoquinoline ring as the base component of structure. These appear to be novel compounds with regard to inhibition of $\mathrm{Cmm}$ growth and when grown in NB medium. Given the seriousness of $\mathrm{Cmm}$-caused bacterial canker and lack of very effective control methods, these compounds would be of great potential as new biocontrol agents for the disease.

Supplementary Materials: The following are available online at https:/ / www.mdpi.com/article/10 .3390 /applmicrobiol1010006/s1. Figure S1: Representative HPLC-UV chromatograms (at 265 nm) from semi-preparative purification of SPE fractions (A) 70\% extract showing two fractions collected. Figure S2: Representative high-resolution extracted ion chromatograms (left) and mass spectra (right) for two fractions (F1 and F2) from 70\% SPE sample, purified by HPLC. F1 and F2 contain molecular species, giving $\mathrm{MH}^{+}$at $m / z 241.1348$ and $m / z$ 255.1490, respectively. The complete ion chromatograms and UV traces (at $254 \mathrm{~nm}$ ) showed no other peaks present in these purified fractions. Figure S3: Anti-Cmm activities of HPLC fractions (1 and 2) collected from 60 and 70\% SPE fractions: (a) $60 \%$ fraction 1 , (b) $60 \%$ fraction 2 , (c) $60 \%$ fraction 3 , (d) $70 \%$ fraction 1 , (e) $70 \%$ fraction 2 , and (f) $50 \%$ acetonitrile (control). Figure S4.1: The ${ }^{1} \mathrm{H}$ and COSY NMR spectra of fraction 1 in MeOD. The proposed structure, which satisfies the chemical data, multiplicities, and COSY correlations, is shown in insert. The numbers in parentheses after the peak positions in the 1-D spectra identify the various protons on the structure. Peaks at 3.3 and $4.8 \mathrm{ppm}$ correspond to residual methanol and water peaks. Figure S4.2: The $\left\{{ }^{1} \mathrm{H}-13 \mathrm{C}\right\}$ HSQC spectrum with multiplicity edition of fraction 1 in methanol-d4. Figure S4.3: Aromatic region of the $\left\{{ }^{1} \mathrm{H}-13 \mathrm{C}\right\}$ HSQC spectra of fractions 1 (top) and 2 (bottom), showing the conserved quinoline peaks. Figure S5. Proposed fragment ions formed from protonated precursor ion at $m / z 241$ based on high-resolution MS/MS data presented in manuscript. Figure S6: Proposed fragment ions and high-resolution MS/MS data from deprotonated precursor ion at $m / z$ 239. Figure S7: Anti-Cmm activity of butanol extracts prepared from (a) nutrient broth, (b) King's B, (c) Luria broth, and (d) tryptic soy broth, and growth of P. entomophila $23 \mathrm{~S}$ in each media (e). 
Author Contributions: Y.T. conducted all the experimental work and wrote the manuscript, except for the section on compound identification, which was written by L.S. The HPLC purification and LC-MS(/MS) analysis were performed by L.S.'s laboratory at UQAM. L.B.O. conducted LC-MS(/MS) and A.A.A. conducted NMR. C.B. prepared the purified compounds for quantitative study. A.S. performed the HPLC for quantitative analysis of anti-Cmm compound production. D.L.S. provided the conceptual framework and guided and supervised overall study. All authors have read and agreed to the published version of the manuscript

Funding: This research was funded by MAPAQ, grant number 811015.

Institutional Review Board Statement: Not applicable.

Informed Consent Statement: Not applicable.

Data Availability Statement: Not applicable.

Conflicts of Interest: The authors declare that the research was conducted in the absence of any commercial or financial relationships that could be construed as a potential conflict of interest.

\section{References}

1. Agrio, G.N. Plant Pathology; Academic Press: London, UK, 2005.

2. Gillor, O.; Ghazaryan, L. Recent advances in bacteriocin application as antimicrobials. Recent Pat. Antiinfect. Drug Discov. 2007, 2, 115-122. [CrossRef]

3. Mnif, I.; Ghribi, D. Potential of bacterial derived biopesticides in pest management. Crop Prot. 2015, 77, 52-64. [CrossRef]

4. Strobel, G.; Daisy, B.; Castillo, U.; Harper, J. Natural products from endophytic microorganisms. J. Nat. Prod. 2004, 67, 257-268. [CrossRef]

5. Ojiambo, P.S.; Scherm, H. Biological and application-oriented factors influencing plant disease suppression by biological control: A meta-analytical review. Phytopathology 2006, 96, 1168-1174. [CrossRef]

6. Wang, X.Y.; Xu, Y.Q.; Lin, S.J.; Liu, Z.Z.; Zhong, J.J. Novel antiphytopathogenic compound 2-heptyl-5-hexylfuran-3-carboxylic acid, produced by newly isolated Pseudomonas sp. strain SJT25. Appl. Environ. Microbiol. 2011, 77, 6253-6257. [CrossRef] [PubMed]

7. Whipps, J.M. Developments in the biological control of soil-borne plant pathogens. Adv. Bot. Res. 1997, $26,1-134$.

8. Raaijmakers, J.M.; De Bruijn, I.; Nybroe, O.; Ongena, M. Natural functions of lipopeptides from Bacillus and Pseudomonas: More than surfactants and antibiotics. FEMS Microbiol. Rev. 2010, 34, 1037-1062. [CrossRef]

9. Haas, D.; Keel, C. Regulation of antibiotic production in root-colonizing Pseudomonas sp. and relevance for biological control of plant disease. Annu. Rev. Phytopathol. 2003, 41, 117-153. [CrossRef] [PubMed]

10. Santoyo, G.; Orozco-Mosqueda, M.D.C.; Govindappa, M. Mechanisms of biocontrol and plant growth-promoting activity in soil bacterial species of Bacillus and Pseudomonas: A review. Biocontrol Sci. Technol. 2012, 22, 855-872. [CrossRef]

11. Takishita, Y.; Charron, J.B.; Smith, D.L. Biocontrol rhizobacterium Pseudomonas sp. 23S induces systemic resistance in tomato (Solanum lycopersicum L.) against bacterial canker Clavibacter michiganensis subsp. michiganensis. Front. Microb. 2018, 9, 2119. [CrossRef]

12. Gleason, M.L.; Gitaitis, R.D.; Ricker, M.D. Recent progress in understanding and controlling bacterial canker of tomato in eastern North America. Plant Dis. 1993, 77, 1069-1076. [CrossRef]

13. de León, L.; Siverio, F.; López, M.M.; Rodríguez, A. Clavibacter michiganensis subsp. michiganensis, a Seedborne Tomato Pathogen: Healthy Seeds Are Still the Goal. Plant Dis. 2011, 95, 1328-1338.

14. Carlton, W.M.; Braun, E.J.; Gleason, M.L. Ingress of Clavibacter michiganensis subsp. michiganensis into tomato leaves through hydathodes. Phytopathology 1998, 88, 525-529. [PubMed]

15. Gartemann, K.H.; Kirchner, O.; Engemann, J.; Gräfen, I.; Eichenlaub, R.; Burger, A. Clavibacter michiganensis subsp. michiganensis: First steps in the understanding of virulence of a Gram-positive phytopathogenic bacterium. J. Biotechnol. 2003, 106, $179-191$.

16. Sharabani, G.; Manulis-Sasson, S.; Borenstein, M.; Shulhani, R.; Lofthouse, M.; Chalupowicz, L.; Shtienberg, D. The significance of guttation in the secondary spread of Clavibacter michiganensis subsp. michiganensis in tomato greenhouses. Plant Pathol. 2013, 62, 578-586.

17. Fatmi, M.; Schaad, N.W.; Bolkan, H.A. Seed treatments for eradicating Clavibacter michiganensis subsp. michiganensis from naturally infected tomato seeds. Plant Dis. 1991, 75, 383-385.

18. Chang, R.J.; Ries, S.M.; Pataky, J.K. Local sources of Clavibacter michiganensis subsp. michiganensis in the development of bacterial canker on tomatoes. Phytopathology 1992, 82, 553-560.

19. Kawaguchi, A.; Tanina, K. Genetic groups of Clavibacter michiganensis subsp. michiganensis identified by DNA fingerprinting and the effects of inoculation methods on disease development. Eur. J. Plant Pathol. 2014, 140, 399-406.

20. Xu, X.; Kumar, A.; Deblais, L.; Pina-Mimbela, R.; Nislow, C.; Fuchs, J.R.; Miller, S.A.; Rajashekara, G. Discovery of novel small molecule modulators of Clavibacter michiganensis subsp. michiganensis. Front. Microbial. 2015, 6, 112. 
21. Hausbeck, M.K.; Bell, J.; Medina-Mora, C.; Podolsky, R.; Fulbright, D.W. Effect of bactericides on population sizes and spread of Clavibacter michiganensis subsp. michiganensis on tomatoes in the greenhouse and on disease development and crop yield in the field. Phytopathology 2000, 90, 38-44.

22. Amkraz, N.; Boudyach, E.H.; Boubaker, H.; Bouizgarne, B.; Aoumar, A.A.B. Screening for fluorescent pseudomonades, isolated from the rhizosphere of tomato, for antagonistic activity toward Clavibacter michiganensis subsp. michiganensis. World J. Microbiol. Biotechnol. 2010, 26, 1059-1065. [CrossRef]

23. Lanteigne, C.; Gadkar, V.J.; Wallon, T.; Novinscak, A.; Filion, M. Production of DAPG and HCN by Pseudomonas sp. LBUM300 contributes to the biological control of bacterial canker of tomato. Phytopathology 2012, 102, 967-973. [CrossRef]

24. Aksoy, H.M.; Kaya, Y.; Ozturk, M.; Secgin, Z.; Onder, H.; Okumus, A. Pseudomonas putida-Induced response in phenolic profile of tomato seedlings (Solanum lycopersicum L.) infected by Clavibacter michiganensis subsp. michiganensis. Biol. Control. 2017, 105, 6-12. [CrossRef]

25. Barda, O.; Shalev, O.; Alster, S.; Buxdorf, K.; Gafni, A.; Levy, M. Pseudozyma aphidis induces salicylic-acid-independent resistance to Clavibacter michiganensis in tomato plants. Plant Dis. 2015, 99, 621-626. [PubMed]

26. Kotan, R.; Dadasoğlu, F.; Karagoz, K.; Cakir, A.; Ozer, H.; Kordali, S.; Cakmakci, R.; Dikbas, N. Antibacterial activity of the essential oil and extracts of Satureja hortensis against plant pathogenic bacteria and their potential use as seed disinfectants. Sci. Hortic. 2013, 153, 34-41. [CrossRef]

27. Özdemir, Z.; Erincik, Ö. Antimicrobial activities of extracts of Cyperus rotundus L. rhizomes against some bacterial and fungal pathogens of strawberry and tomato. Arch. Phytopathol. Plant Protect. 2015, 48, 850-861.

28. Li, S.; Jin, X.; Chen, J.; Lu, S. Inhibitory activities of venom alkaloids of Red Imported Fire Ant against Clavibacter michiganensis subsp. michiganensis in vitro and the application of piperidine alkaloids to manage symptom development of bacterial canker on tomato in the greenhouse. Int. J. Pest Manag. 2013, 59, 150-156.

29. Choi, J.; Baek, K.H.; Moon, E. Antimicrobial Effects of a Hexapetide KCM21 against Pseudomonas syringae pv. tomato DC3000 and Clavibacter michiganensis subsp. michiganensis. Plant Pathol. J. 2014, 30, 24.

30. Souleimanov, A.; Prithiviraj, B.; Smith, D.L. The major Nod factor of Bradyrhizobium japonicum promotes early growth of soybean and corn. J. Exp. Bot. 2002, 53, 1929-1934. [CrossRef] [PubMed]

31. Pitkin, D.H.; Martin-Mazuelos, E. Bioassay Methods for Antimicrobial and Antifungal Agents. In Antimicrobial Susceptibility Testing Protocols; CRC Press: Boca Raton, FL, USA, 2007; p. 313.

32. Wiegand, I.; Hilpert, K.; Hancock, R.E. Agar and broth dilution methods to determine the minimal inhibitory concentration (MIC) of antimicrobial substances. Nat. Protoc. 2008, 3, 163-175. [CrossRef]

33. Ricci, E.C. Investigating the Role of Pseudomonas sp. and Bacillus sp. Biofilms as Plant Growth Promoting Inoculants. Master's Thesis, McGill University, Montreal, QC, Canada, December 2015.

34. Qing, Z.X.; Yang, P.; Tang, Q.; Cheng, P.; Liu, X.B.; Zheng, Y.J.; Liu, Y.S.; Zeng, J.G. Isoquinoline alkaloids and their antiviral, antibacterial, and antifungal activities and structure-activity relationship. Curr. Org. Chem. 2017, 21, 1920-1934. [CrossRef]

35. Sato, F.; Kumagai, H. Microbial production of isoquinoline alkaloids as plant secondary metabolites based on metabolic engineering research. Proc. Jpn. Acad. Ser. B 2013, 89, 165-182. [CrossRef] [PubMed]

36. Baccile, J.A.; Spraker, J.E.; Le, H.H.; Brandenburger, E.; Gomez, C.; Bok, J.W.; Macheleidt, J.; Brakhage, A.A.; Hoffmeister, D.; Keller, N.P.; et al. Plant-like biosynthesis of isoquinoline alkaloids in Aspergillus fumigatus. Nat. Chem. Biol. 2016, 12, 419-424. [CrossRef]

37. Nord, C.; Levenfors, J.J.; Bjerketorp, J.; Sahlberg, C.; Guss, B.; Öberg, B.; Broberg, A. Antibacterial Isoquinoline Alkaloids from the Fungus Penicillium Spathulatum Em19. Molecules 2019, 24, 4616.

38. Solecka, J.; Zajko, J.; Postek, M.; Rajnisz, A. Biologically active secondary metabolites from Actinomycetes. Open Life Sci. 2012, 7, 373-390. [CrossRef]

39. Zhao, Z.M.; Shang, X.F.; Lawoe, R.K.; Liu, Y.Q.; Zhou, R.; Sun, Y.; Yan, Y.F.; Li, J.C.; Yang, G.Z.; Yang, C.J. Anti-phytopathogenic activity and the possible mechanisms of action of isoquinoline alkaloid sanguinarine. Pestic. Biochem. Physiol. 2019, 159, 51-58. [CrossRef] [PubMed]

40. Zaki, R.M.; Kamal El-Dean, A.M.; Radwan, S.M.; Sayed, S.M. Synthesis and Antimicrobial Activity of Novel Piperidinyl Tetrahydrothieno [2, 3-c] isoquinolines and Related Heterocycles. ACS Omega 2019, 5, 252-264. [CrossRef]

41. Galán, A.; Moreno, L.; Párraga, J.; Serrano, Á.; Sanz, M.J.; Cortes, D.; Cabedo, N. Novel isoquinoline derivatives as antimicrobial agents. Bioorg. Med. Chem. 2013, 21, 3221-3230.

42. Zielińska, S.; Wójciak-Kosior, M.; Dziagwwa-Becker, M.; Gleńsk, M.; Sowa, I.; Fijałkowski, K.; Rurańska-Smutnicka, D.; Matkowski, A.; Junka, A. The Activity of Isoquinoline Alkaloids and Extracts from Chelidonium majus against Pathogenic Bacteria and Candida sp. Toxins 2019, 11, 406. [CrossRef]

43. Cushnie, T.T.; Cushnie, B.; Lamb, A.J. Alkaloids: An overview of their antibacterial, antibiotic-enhancing and antivirulence activities. Int. J. Antimicrob. Agents 2014, 44, 377-386.

44. Diamond, A.; Desgagné-Penix, I. Metabolic engineering for the production of plant isoquinoline alkaloids. Plant Biotechnol. J. 2016, 14, 1319-1328. [CrossRef] [PubMed]

45. Vining, L.C. Functions of secondary metabolites. Annu. Rev. Microbiol. 1990, 44, 395-427. [CrossRef] [PubMed] 